\title{
Northern Red-Oak Kermes, Kermes Scale (suggested common names), Allokermes kingii (Cockerell) (Insecta: Hemiptera: Coccoidea: Kermesidae) ${ }^{1}$
}

Jay Cee Turner and Eileen Buss ${ }^{2}$

\section{Introduction}

In North America there are 32 species of Kermesidae in five genera, but in northeastern North America there are only nine species in four genera (Eriokermes, Nanokermes, Allokermes, and Kermes). The Allokermes spp. that are of economic importance in Florida are A. cueroensis (Cockerell), A. galliformis (Riley), and A. kingii (Cockerell). The kermes scale, Allokermes kingii (Cockerell), is an important pest on oak (Quercus spp.) trees.

\section{Synonymy}

Kermes kingii; Cockerell, 1898 ca. Misspelling of species name.

Talla kingii; Lindinger, 1933. Change of combination and misspelling of species name.

Allokermes kingii; Bullington and Kosztarab, 1985. Described: female. Illustrated. Change of combination and misspelling of species epithet.

\section{Distribution}

Allokermes kingii is native to North America, but occurs throughout the world. It occurs in 32 states in the U.S., and is largely absent in the western states. In Florida, A. kingii occurs in Alachua, Gilchrist, Hendry, Pinellas and Polk Counties (Scalenet 2004).

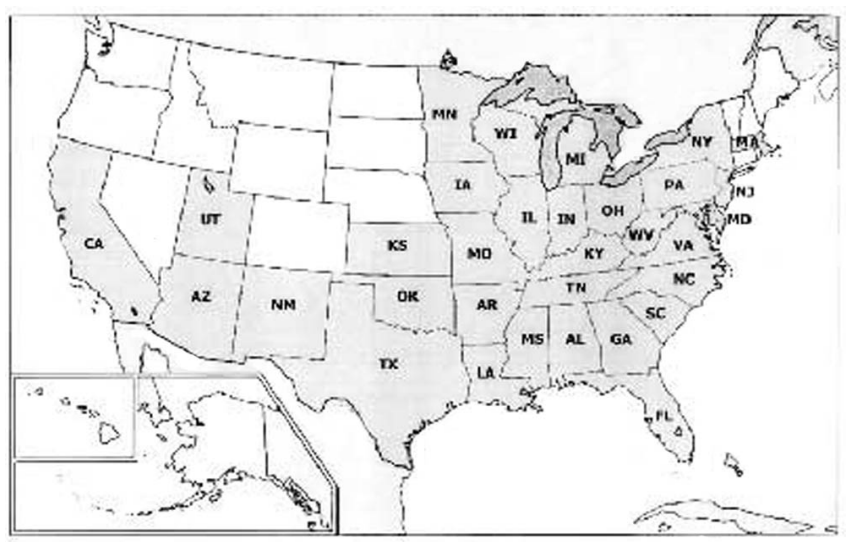

Figure 1. Distribution of Allokermes kingii in the United States as of 2004. Credits: Scalenet, http://www.sel.barc.usda.gov/

1. This document is EENY-338, one of a series of Featured Creatures from the Entomology and Nematology Department, Florida Cooperative Extension Service, Institute of Food and Agricultural Sciences, University of Florida. Published: November 2004. This document is also available on Featured Creatures Website at http://creatures.ifas.ufl.edu. Please visit the EDIS Website at http://edis.ifas.ufl.edu.

2. Jay Cee Turner and Eileen Buss, Department of Entomology and Nematology, Institute of Food and Agricultural Sciences, University of Florida, Gainesville, FL.

The Institute of Food and Agricultural Sciences (IFAS) is an Equal Opportunity Institution authorized to provide research, educational information and other services only to individuals and institutions that function with non-discrimination with respect to race, creed, color, religion, age, disability, sex, sexual orientation, marital status, national origin, political opinions or affiliations. U.S. Department of Agriculture, Cooperative Extension Service, University of Florida, IFAS, Florida A. \& M. University Cooperative Extension Program, and Boards of County Commissioners Cooperating. Larry Arrington, Dean 


\section{Description}

The taxonomy of A. kingii was described by Hamon et al. (1976).

Eggs: Eggs are $0.32 \mathrm{~mm}$ long, are oval in shape and range in color from white to orange. They are deposited into a brood chamber, beneath the female scale, and are covered with a layer of wax (Tamaki et al 1969, Hamon et al 1975).

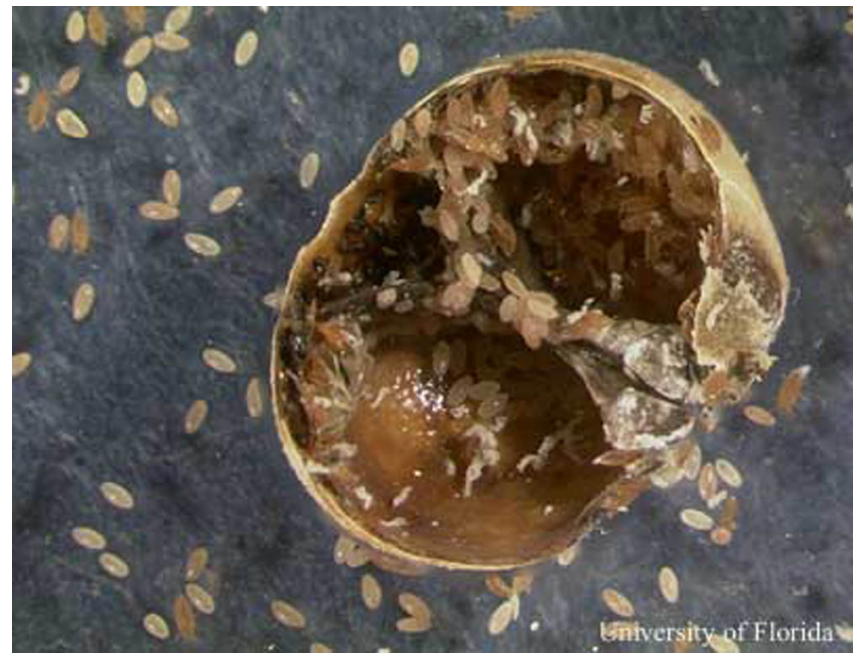

Figure 2. Eggs inside brood chamber of female scale Allokermes kingii (Cockerell). Credits: Lyle J. Buss, University of Florida

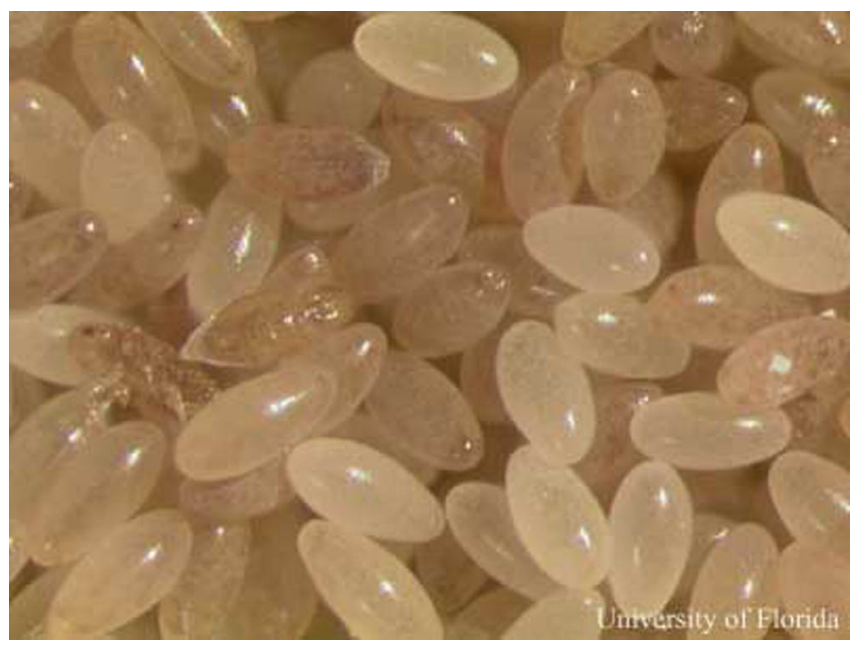

Figure 3. Eggs and eclosing (emerging from egg) nymphs of the scale Allokermes kingii (Cockerell). Credits: Lyle J. Buss, University of Florida

Nymphs: First instars are about $0.43 \mathrm{~mm}$ long, salmon-colored, oblong to oval, widest at the mesothorax, and taper posteriorly. The antennae are six-segmented, and the dorsal tubular ducts are usually absent. The legs are well developed, five-segmented, and have a single curved claw. There are no morphological differences in first instar males and females, but sexual dimorphism becomes apparent in the second instar. The third instar differs from second instar and adult by the number of dermal structures, having more than the second instar and less than the adult.

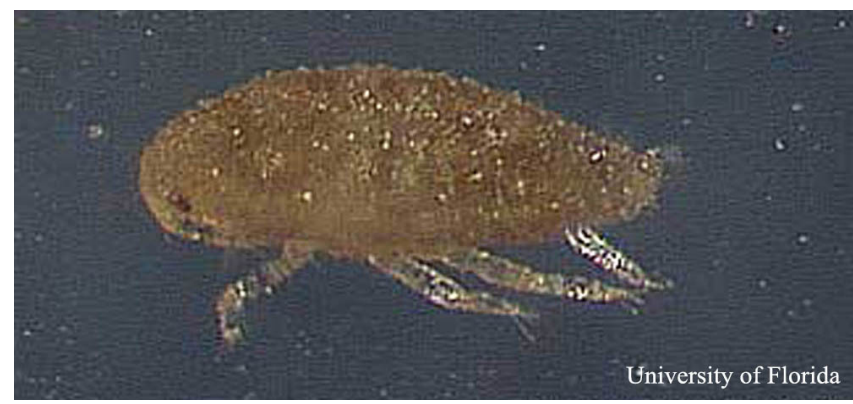

Figure 4. Ventral view of first instar of the scale Allokermes kingii (Cockerell). Credits: Lyle J. Buss, University of Florida

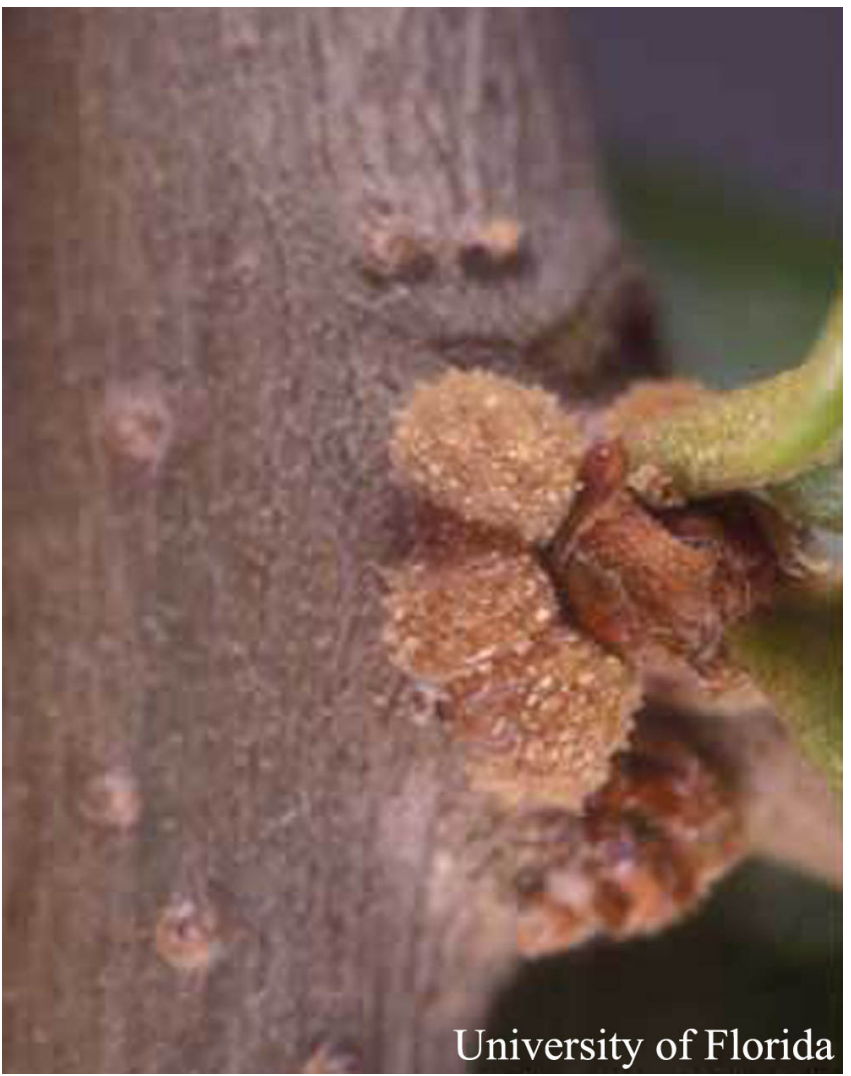

Figure 5. Lateral view of second instar of the scale Allokermes kingii (Cockerell). Credits: L.J. Buss, University of Florida

Male pre-pupa: Pre-pupa measures $2.0 \mathrm{~mm}$ long and is salmon-colored. Antennae are partly segmented, rounded, and wide at base. Wing pads are 
budlike, legs are poorly developed, and the head is not clearly separated from the prothorax.

Male pupa: Pupa measures $2.3 \mathrm{~mm}$ long, is elongated and is salmon-colored. Antennae are tensegmented. Wing pads are elongated and rounded, legs are four-segmented without a claw. Head is not clearly separated from prothorax.

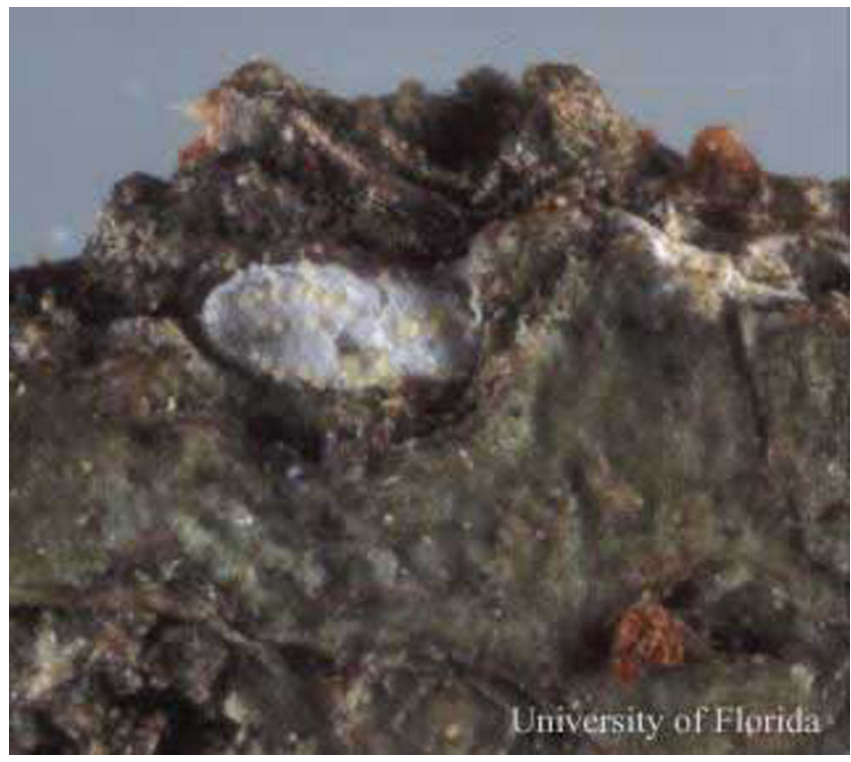

Figure 6. Ventral view of male test (waxy covering of pre-pupa and pupa) of the scale Allokermes kingii (Cockerell). Credits: Jay Cee Turner, University of Florida

Adult males: Adult males measure $1.0 \mathrm{~mm}$ long, are elongated, are widest in the thoracic area and narrow posteriorly. Newly emerged males are red to light brown. Antennae are 10-segmented and well developed. They have six pairs of simple eyes. Wings are large and fragile looking, legs are well developed and slender, and the claw has a minute denticle. Head is distinctly separated from thorax.

Adult females: Adult females are about $5 \mathrm{~mm}$ long, $4.3 \mathrm{~mm}$ wide, and about $3.5 \mathrm{~mm}$ high. Adult females are covered with a protective shell that is an integral part of their bodies. The secretion of wax from pores creates a very convex shell. The color is pale brownish-yellow, marbled with a slightly darker red tint, with small black spots covering the entire surface. Antennae and legs have six and five segments, respectively. Although antennae and legs have the same number of segments as nymphs, the antennae and legs are reduced in size.

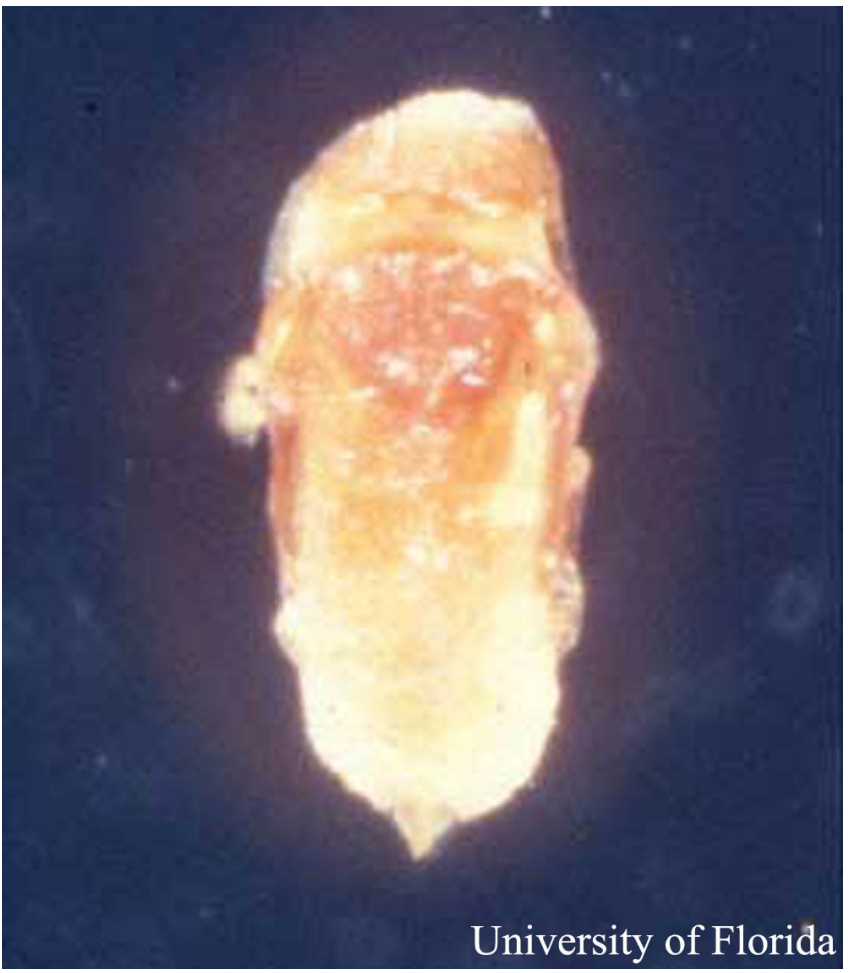

Figure 7. Ventral view of male pupa, Allokermes kingii (Cockerell). Credits: Jerry Butler, University of Florida

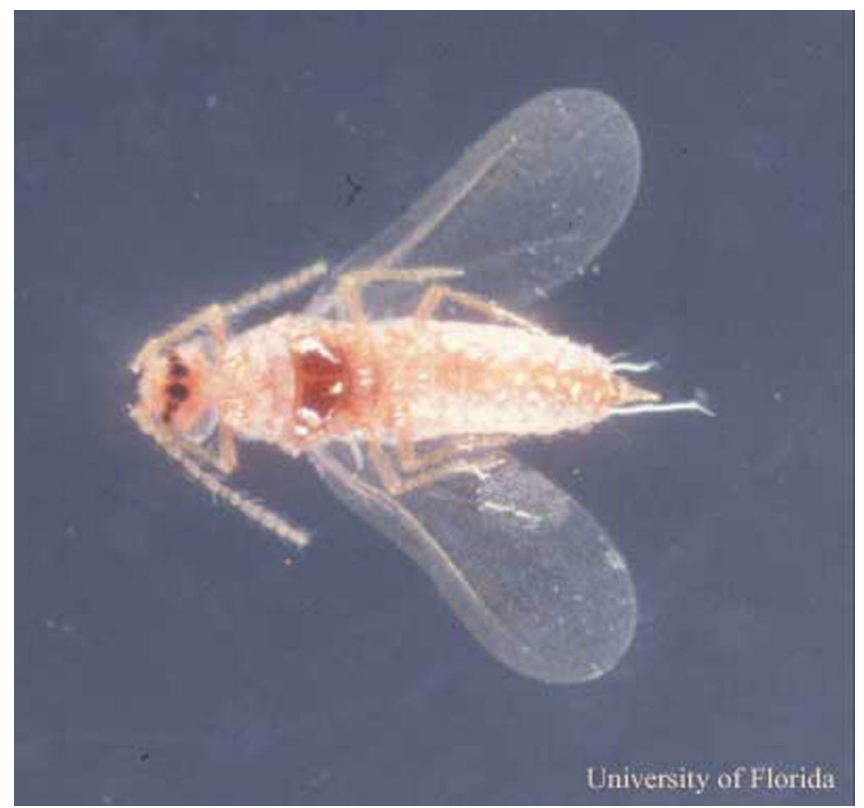

Figure 8. Ventral view of adult male, Allokermes kingii (Cockerell), a scale. Credits: Jerry Butler, University of Florida

\section{Life Cycle}

Hamon described the biology of A. kingii in 1976 in Blacksburg, VA. It is univoltine (one generation per year) in Virginia, but is bivoltine (two generations per year) in Florida's subtropical climate 


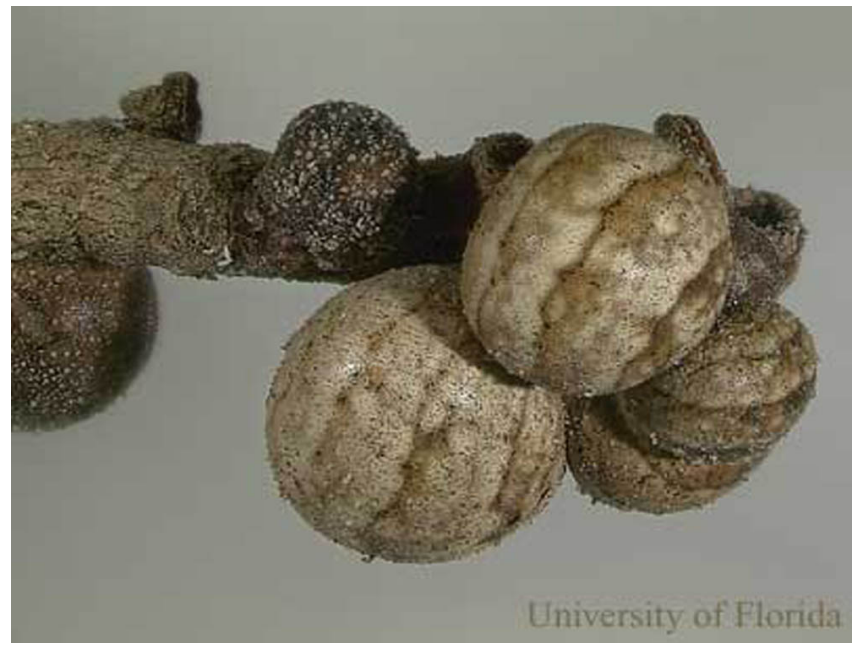

Figure 9. Ventral view of adult female, Allokermes kingii (Cockerell), a scale. Credits: L.J. Buss, University of Florida

(Turner 2004). Allokermes kingii males develop with complete metamorphosis while female A. kingii develop with a simple metamorphosis (Hamon et al. 1976, Kosztarab 1987, Ben-Dov 1997, Marotta 1997, Daly et al. 1998).

In Florida, first generation crawlers emerge in late May (Turner 2004). After hatching the first instar or crawler remains beneath the parental brood chamber until environmental conditions favor its dispersal. Females migrate to large branches and males crawl to bark crevices on the tree stem. Crawlers begin to molt into second instars by mid-July. Second instar females migrate to tree wounds or new growth, often near new leaf petioles, become sessile, and secrete a hard, waxy covering over themselves. Second instar males migrate further down on the tree stems, become sessile, and cover themselves with a white, felt-like waxy pupal case (test). Second instar females molt to a third instar, which lasts approximately two to four days. Third instar females become adults from late August to mid-December.

Eggs are laid into brood chambers from early September to mid-December. Each female can lay an average of 3,000 eggs (Hamon et al. 1975). The female's abdomen shrinks after the eggs are laid. Dead females may remain on the host plant for a year or more after first instar emergence (Baer 1980).

Second generation crawlers begin emerging in mid-September and molt into second instars by mid-October. First and second instars overwinter on trees. Scale development appears to slow or stop until the first molt in mid-February. By late April, second instar female $A$. kingii become mature adults. Second-generation adult female $A$. kingii lay eggs until mid-June.

Male pre-pupae are present on the bark from early June to mid-October. Pupae occur from May to the end of October. Adult males are present from late May to the end of October. The adult male has non-functioning mouthparts and lives for a few hours to a week.

Adult females are neotenic, which is a prolonged larval form in a sexually mature organism. Because adult females are neotenous, they are able to mate with males at a young age (Gullan \& Kosztarab 1997). The lumen of the adult male contains numerous sperm bundles in a liquid surrounded by a sheath (Foldi 1997, Gullan \& Kosztarab 1997). After mating with the female the sperm bundles are stored in the oviduct. If the male mates with a teneral female, a condition of an insect after molting but before the new cuticle has hardened, then fertilization may need to be delayed for weeks or months until eggs are mature (Gullan \& Kosztarab 1997).

\section{Hosts}

All records of infestation are reported from Quercus spp. except for one record on Castanopsis in California (Ferris 1955) and Junipercus sp.

Allokermes kingii occur on $Q$. borealis (Michaux), $Q$. coccinea (Muenchhausen), Q. geminata (Small), $Q$. ilicifolia (Wangenheimd), Q. imbricaria (Michaux), Q. laurifolia (Michaux), Q. phellos (Linnaeus), $Q$. rubra (Linnaeus), $Q$. velutina (Lamarck), and $Q$. virginiana (Miller). The primary hosts are $Q$. borealis and $Q$. velutina. Five of the oak species, $Q$. geminata, $Q$. laurifolia, $Q$. phellos, $Q$. velutina, and $Q$. virginiana occur in Florida.

\section{Economic Importance}

Allokermes kingii directly affect plant growth by their feeding, which involves the penetration of their stylets into the phloem and the uptake of sap as food (Raven 1983, Vranjic 1997). The feeding results in branch dieback, reduced tree growth rates, and sooty mold, which grows on the honeydew secreted by the 
scales (Vranjic 1997). Tree death may occur during heavy infestations.

\section{Management}

Mechanical. Pruning, removal of scales by hand, and destroying infested plant material may minimize infestations.

Natural enemies. Several natural enemies attack A. kingii, including ladybird beetles (Coleoptera: Coccinellidae), lacewings (Neuroptera: Chrysopidae), moth larvae (Lepidoptera: Blactobasidae, Cosmopterigidae, Pyralidae), and parasitoids (Hymenoptera: Encyrtidae, Ichneumonidae).

Chemical. Scale management is difficult because the scale is often covered with a protective waxy cover. Control methods should be targeted toward the first instar or early second instar. Traditionally, scales have been treated with insecticidal oils as well as a variety of other pesticides. Consult a local Cooperative Extension Service office for current control recommendations.

For more information please see:

Scale Insects and Mealybugs on Ornamental Plants (http://edis.ifas.ufl.edu/MG005)

Florida Insect Management Guide for Ornamentals

(

http://edis.ifas.ufl.edu/

TOPIC_GUIDE_IG_Ornamentals)

\section{Selected References}

Baer RG. 1980. A new species of gall-like coccid from southeastern United States. Journal of Georgia Entomological Society 15: 20-25.

Ben-Dov Y. 1997. Morphology, systematics and phylogeny, pp. 3-4. In Ben-Dov Y, Hodgson CJ (eds.), Soft scale insects: Their biology, natural enemies and control, vol. 7A. Elsevier, Amsterdam, The Netherlands.

Bullington SW, Kosztarab M. 1985. Revision of the family Kermesidae (Hemiptera) in the Nearctic region based on adult and third instar females, pp 4-67. In Baer RG, Bullington SW, Kosztarab M (eds.), Morphology and systematics of scale insects, vol. 2. Virginia Polytechnic Institute and State University, Blacksburg, VA.

Daly HV, Doyen JT, Purcell III AH. 1998. Continuity of the generations: development and reproduction, pp. 66-68. In Daly HV, Doyen JT, Purcell III AH (eds.), Introduction to insect biology and diversity, 2nd ed. Oxford University Press, New York, NY.

Foldi I. 1997. Internal anatomy of the adult female, pp. 73-90. In Ben-Dov Y, Hodgson CJ (eds.), Soft scale insects: Their biology, natural enemies and control, vol. 7A. Elsevier, Amsterdam, The Netherlands.

Gullan PJ, Kosztarab M. 1997. Adaptations in scale insects. Annual Review of Entomology 42: 23-50.

Hamon AB. 1977. Gall-like scale insects (Kermes spp.) (Homoptera: Coccoidea: Kermesidae). Entomology Circular number 178: 1-2.

Hamon AB, Lambdin PL, Kosztarab M. 1975. Eggs and wax secretion of Kermes kingii. Annals of the Entomological Society of America 68:

1077-1078.

Hamon AB, Lambdin PL, Kosztarab M. 1976. Life history and morphology of Kermes kingii in Virginia (Homoptera: Coccoidea: Kermesidae). Virginia Polytechnic Institution \& State University Research Division Bulletin 111: 1-31.

Kosztarab M. 1987. Everything unique or unusual about scale insects (Homoptera: Coccoidae). Bulletin of the Entomological Society of America 33: 215-220.

Kosztarab M. 1996. Scale insects of northeastern North America. Identification, biology, and distribution. Virginia Museum of Natural History, Martinsburg, Virginia. 650 pp.

Marotta S. 1997. General life history, pp. 251-256. In Ben-Dov Y, Hodgson CJ (eds.), Soft 
scale insects: Their biology, natural enemies and control, vol. 7A. Elsevier, Amsterdam, The Netherlands.

Raven JA. 1983. Phytophages of xylem and phloem: a comparison of animal and plant sapfeeders. Advances in Ecological Research 13: $135-234$.

Scalenet. (2004). Scales on Fagaceae Quercus. http://www.sel.barc.usda.gov/ (June 2004).

Tamaki Y, Yushima T, Kawai S. 1969. Wax secretion in a scale insect, Ceroplastes pseudoceriferus Green (Hemiptera: Coccidae). Applied Entomology and Zoology 4: 126-134.

Turner JC. 2004. Biology and management of Allokermes kingii (Hemiptera: Kermesidae) on oak trees. M.S. Thesis, University of Florida, Gainesville, FL.

Vranjic JA. 1997. Effects on host plant, pp. 323-336. In Ben-Dov Y, Hodgson CJ (eds.), Soft scale insects: Their biology, natural enemies and control, vol. 7A. Elsevier, Amsterdam, The Netherlands. 